\title{
ACRL honors outstanding contributions to academic librarianship
}

\section{Drake named winner of Arkinson award}

Miriam A. Drake, dean and director of libraries at the Georgia Institute of Technology is the recipient of the Hugh $C$. Atkinson Memorial Award. The award is for outstanding accomplishments of an academic librarian who has worked in the areas of library automation or library management and has made contributions (including risk taking) towards the improvement of library services, or to library development or research.

"Miriam Drake

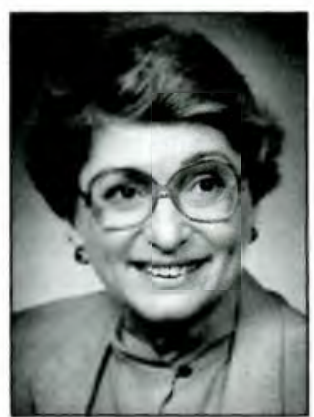

Miriam Drake has been in the forefront of the movement to change the way in which users interact with the information resources of the library and the campus," said Michelle Dalehite, chair Hugh Atkinson Memorial Award Jury. "Through the Georgia Tech Electronic Library (GTEL), she took a bold direction that has served as a model and inspiration for others in the field. I am particularly pleased to chair the committee the year that the first woman recipient is to be honored."

Drake will receive this award (a cash prize of $\$ 2,000$ and a citation) during the ALA Annual Conference in San Francisco at the LITA President's Program on Monday, June 29, 1992.

The Hugh C. Atkinson Memorial Award is jointly sponsored by ACRL, the Association for Library Collections and Technical Services (ALCTS), the Library Administration and Management Association (LAMA), and the Library and Information Technology Association (IITA), four divisions of the American Library Association. The award is funded by an endowment created by division, individual, and vendor contributions given in memory of Hugh $\mathrm{C}$. Atkinson.

\section{Doctoral Dissertation Fellowship awarded to Rosie Albritton}

Rosie L. Albritton, Ph.D. candidate at the University of Illinois-Urbana School of Library and Information Science, has been chosen to re ceive the ACRL/ISI Doctoral Dissertation Fellowship. Albritton's proposed dissertation is entitled "Transformational vs. Transactional Leadership in University Libraries: A Field Study for the Model and Its Relationship to Perceived Organizational Effectiveness and Selected Demographics."

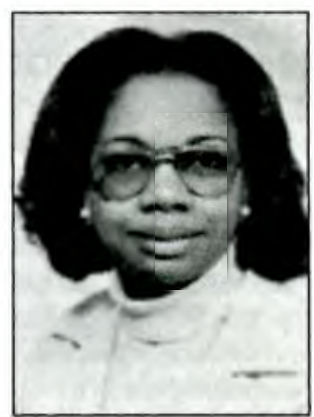

Rosie Albritton
"Ms. Albritton's research is timely and significant in that transformational and charismatic leadership studies are of current interest within the profession and are on the cutting edge of research having to do with leadership," said Roger W. Durbin, chair of the award jury. "Her topic has a strong academic library focus and her approach is original through applying a model from social science research to library management. The award, $\$ 1,000$ and a plaque, is donated by the Institute for Scientific Information and will be presented at the ACRL President's Program in San Francisco, Monday, June 29, 1992.

\section{Baker named Dudley Bibliographic Instruction Librarian}

Betsy K. Baker, head of the Reference Department at Northwestern University Library, is the recipient of ACRL's Bibliographic Instruction Section's Miriam Dudley Bibliographic Instruction Librarian Award.

The award is for contribution to the advancement of bibliographic instruction that has an 
impact on concepts and methods of teaching bibliography and bibliographic instruction.

Baker will receive a $\$ 1,000$ award and a plaque donated by Mountainside Publishing Company on behalf of their journal $R e$ search Strategies.

"Betsy Baker's ground-breaking research explores cognitive approaches to teaching. She has raised awareness throughout the higher education community of the critical importance of information skills

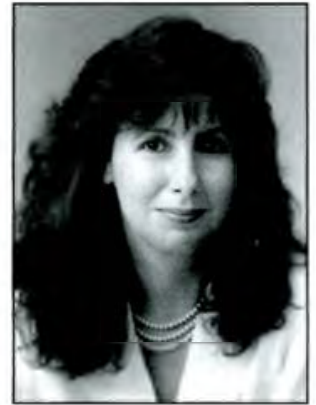

Betsy Baker to student's personal and academic success. Her career accomplishments in teaching in libraries are a model of success for an individual still relatively young in the profession," said Betsy Wilson, chair of the award jury. "Betsy's greatest contribution may be in her unselfish mentoring and teaching of the next generation of bibliographic instruction librarians."

The award and plaque will be presented at the ACRL Bibliographic Instruction Section program on Sunday, June 28, 1992, in San Francisco.

\section{St. Petersburg Junior College collection development program recognized}

The Library Collection Development Committee at St. Petersburg Junior College, St. Petersburg, Florida, is the recipient of the EBSCO
Community College Learning Resources Achievement Award for Program Development. The members of the committee are: Glenda Alvin, Melissa R. Greenfield, Lora Hunter, Donna Kelly, Dave Lichtenfels, Mary Jane Marden, and Susan Anderson.

Over a period of one school year, 1990-91, the Collection Development Committee cooperatively designed procedures for the implementation of an innovative collection development policy to meet the needs of the college community. The committee shared a draft of its proposals with academic departments, administrators, and student representatives, and welcomed their suggestions. "This is an outstanding collection development policy," said Marilyn McDonald, chair of the award jury. "A great deal of thought and work went into this policies and procedures manual for collection development. It will have universal application to most library operations."

The $\$ 500$ award donated by EBSCO Subscription Services will be presented at ACRL's Community \& Junior College Libraries Section's (CJCLS) annual business meeting in San Francisco, Saturday, June 27, 1992.

\section{Dumont gets award for leadership in community colleges}

Paul E. Dumont, director of technical services, Dallas County Community College District, Dallas, Texas, is the recipient of the EBSCO Community College Learning Resources Achievement Award for Leadership.

Dumont is a long-time advocate ofneeds of learning resource centers. "Paul has a long and

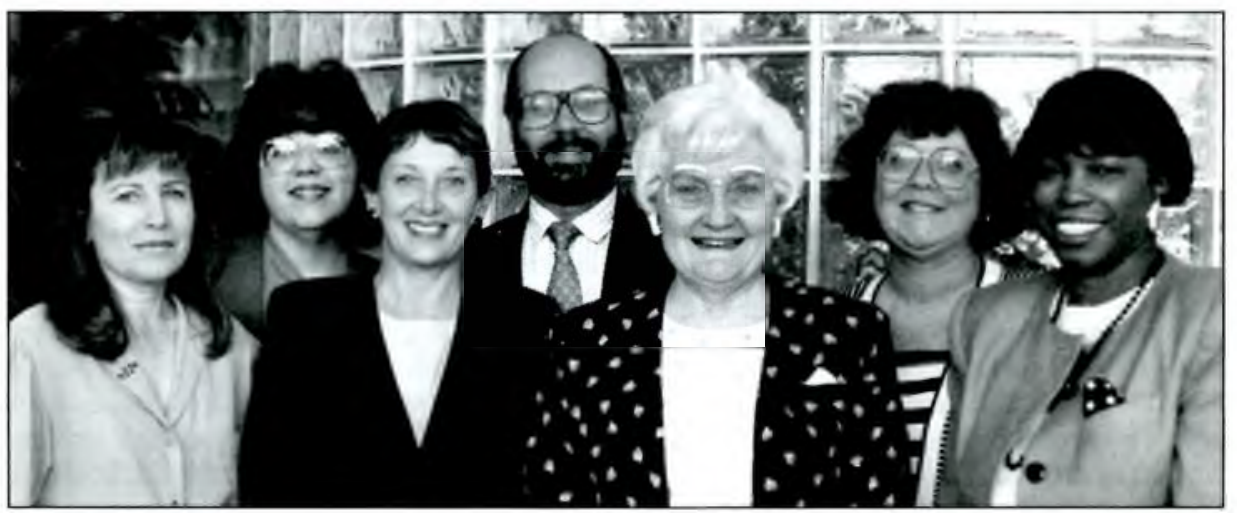

Members of the St. Petersburg Junior College Library Collection Development Committee are (1 to r): Donna Kelly, Melissa Greenfield, Susan Anderson, Dave Lichtenfels, Lora Hunter, Mary Jane Marden, and Glenda Alvin. 
distinguished history of leadership and service to the library community," said award jury chair Marilyn McDonald." The committee is proud to present this award to such a deserving individual."

"In his role as director of technical services, Paul has led our district learning research centers through two generations of automated services," said Pamela Quinn, director/ educational telecommunications, Dallas County Community College District, in her letter

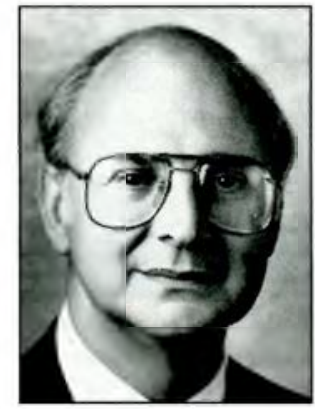

Paul Dumont nominating Dumont. "Paul is a frequent speaker at library conferences and has published of several articles. His views are representative of the community colleges throughout the nation."

The $\$ 500$ award donated' by EBSCO Subscription Services will be presented at the CJCLS annual business meeting in San Francisco, Saturday, June 27, 1992.

\section{Exhibition catalogs recognized by Leab awards}

The Katharine Kyes Leab and Daniel J. Leab American Book Prices Current Exhibition Catalogue Awards have been announced by the

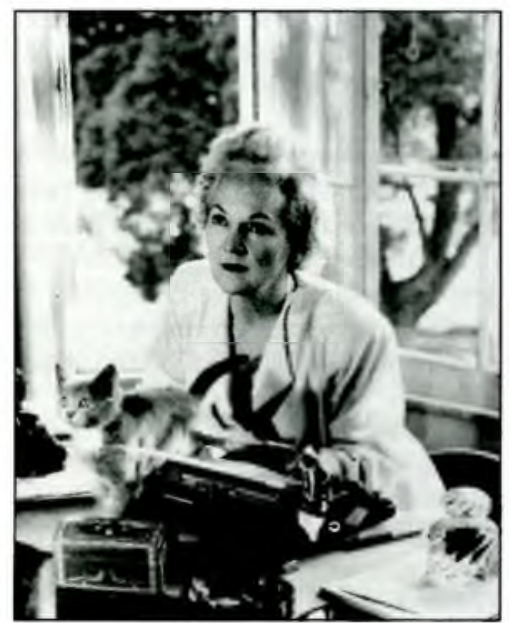

From "Katherine Anne Porter at One Hundred: New Perspectives," McKeldin Lbrary, University of Maryland
Rare Books and Manuscripts Section (RBMS) of ACRL. First place winners in the three divisions - expensive, moderate, and inexpensiveand institutions submitting the catalogues were: "Katharine Anne Porter at One Hundred: New Perspectives," submitted by Special Collections, McKeldin Library, University of Maryland (first division); "Eric Gill: His Life and Art," submitted by the Thomas Fisher Rare Book Library, University of Toronto (second division); and "From Palm to Pine: Rudyard Kipling, 18651936," submitted by Special Collections, University of Virginia Library (third division). Honorable mentions were given for "A Spirit of Joy," submitted by the Bruce Peel Special Collections Library, University of Alberta Libraries (first division) and "W. B. Yeats and the Irish Renaissance," submitted by the Department of Special Collections, Stanford University Libraries (second division). "This year 69 catalogs were submitted and they reflect the excellent exhibitions and fine research that is done in their institutions," said Marvin J. Taylor, chair of the award jury. Printed citations will be presented to the award winners at the RBMS program in San Francisco on June 28, 1992.

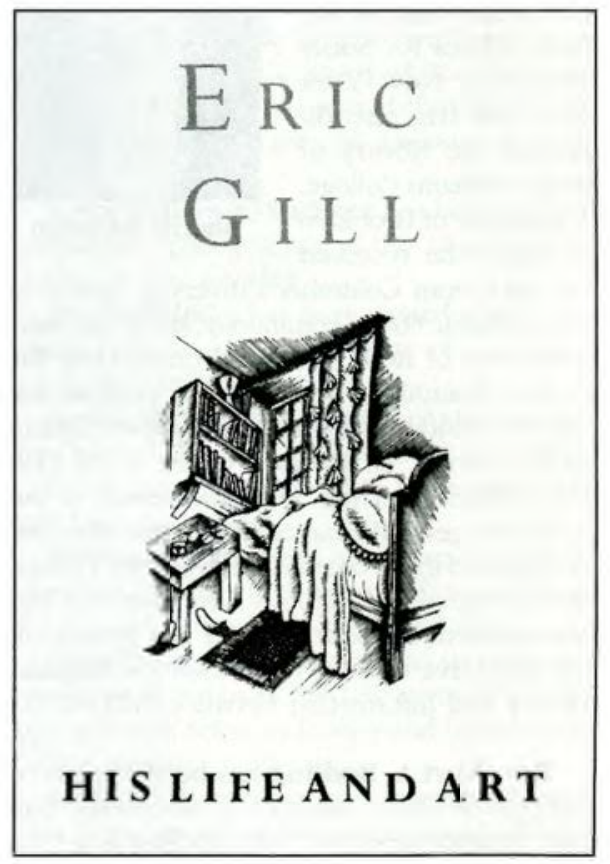

"Eric Gill: His Life and Art," Thomas Fisher Rare Book Library, University of Toronto 